\title{
FISH TRADING: A TOOL FOR SOCIO-ECONOMIC ENHANCEMENT AND POVERTY ALLEVIATION
}

\author{
* AGBON A.O. ${ }^{1},{ }^{1}$ I.T. OMONIYI, ${ }^{1}$ F.I. ADEOSUN, ${ }^{1}$ W.O. ABDUL, $\&{ }^{2}$ C.A. AGBON \\ ${ }^{1}$ Department of Aquaculture and Fisheries Management, University of Agriculture, Abeokuta.
}

Copyright 2010, Fisheries Society of Nigeria.

This paper was prepared for presentation at the $25^{\text {th }}$ Annual International Conference and Exhibition in Administrative Staff College of Nigeria (ASCON), Topo-Badagry, Lagos, Nigeria, $25^{\text {th }}-29^{\text {th }}$ October, 2010.

This paper was selected for presentation by an FISON Program Committee following review of information contained in an abstract submitted by the following review of information contained in an abstract submitted by the
author(s). Contents of the paper, as presented, have not been reviewed by author(s). Contents of the paper, as presented, have not been reviewed by the Fisheries Society of Nigeria and are subject to correction by the author(s). The material, as presented, does not necessarily reflect any position of the Fisheries Society of Nigeria, its officers, or members. Papers presented at FISON meetings are subject to publication review by Editorial Committees of the Fisheries Society of Nigeria. Electronic reproduction, distribution, or storage of any part of this paper for commercial purposes without the written consent of the Fisheries Society of Nigeria is prohibited. Permission to reproduce in print is restricted to an abstract of not more than 300 words; illustrations may not be copied. The abstract must contain conspicuous acknowledgement of where and by whom the paper was presented. Write Librarian, Fisheries Society of Nigeria (FISON), P. O. Box 2607 Apapa, Lagos.

\section{ABSTRACT}

A study was conducted in Abeokuta, the Ogun State capital with the objective to investigate if fish trading could be a tool of poverty alleviation and socio-economic enhancement of the status of women in the household. A total of 120 correctly completed, structured and pre-tested questionnaires, out of the 150 administered to respondents, were retrieved for data analyses. Demographic data of the traders showed that all the respondents were women whose ages ranged from 15 to above 45 years. The ages of 33-45 years constituted 33.3\% of the respondents while the age bracket of between 27-32 years constituted 23.3\%. Majority (73.3\%) were married while $25 \%$ were single-headed households (divorced or widowed). The study revealed that most of the respondents (approximately 61\%) were able to meet their family expenditure jointly with their spouses while $28.3 \%$ of the respondents met the financial responsibilities of their families solely from the profit. Access to credit was found to be a major limitation. The study further revealed that $86.7 \%$ of the respondents would like to continue with the business because they were satisfied with the profit accruable to them from the trade.

\section{INTRODUCTION}

Fish harvesting, handling, processing, storage and distribution provide livelihood for millions of people in many countries (Al-Jufaili and Opara, 2006; Offem et al., 2008). In a recent report on global fish trade, Eurofish-FAO (2007) stated that in 2005 , there was a growth of $8.9 \%$ in fish trade. According to FAO (2009), Capture fisheries and aquaculture supplied the world with about 110 million tonnes of food fish in 2006, providing an apparent per capita supply of $16.7 \mathrm{~kg}$, which is among the highest on record. At a recent press briefing, the Council of Fellows (CoF, 2010) reported that the total fish consumption in Nigeria was more than 1.2 million MT with an estimated national demand as high as 2.66 million MT. It also noted that fish marketing has a wholesale value of over $\$ 1$ billion contributing about $4 \%$ to the GDP. No wonder, the continuing increase in fish income corroborates the government's growth strategy for the sector as articulated in vision 2020 to raise the share of GDP from $1.1 \%$ in 1995 to about $5 \%$ in 2020 .

Fishery occupies a very significant position in the primary sector providing employment for over a million people and contributing about $50 \%$ of animal protein intake of the Nigerian population, particularly the resource poor (CoF, 2010). FAO (2009) reported that the demand for food that promotes health and well-being has increased in recent years. Aall (1982) reported that fish is the poor man's animal protein. Overall, fish provided more than 2.9 billion people with at least $15 \%$ of their average per capita animal protein intake. The share of fish proteins in total world animal protein supplies grew from $14.9 \%$ in 1992 to a peak of $16.0 \%$ in 1996 
but later declined to about $15.3 \%$ in 2005 (FAO, 2009). It has been reported that both pre-harvest and post-harvest activities in fisheries can generate significant profits, prove resilient to shocks and crises, and make meaningful contributions to poverty alleviation and food security (Agbon et al., 2000; Al-Jufaili and Opara, 2006; Offem et al., 2008; Davies et al., 2009).

Marketing is considered successful, when customer satisfaction is accompanied by profit to all those involved in the production and distribution of the goods. Gregory et al. (1994) reported that marketing creates satisfaction or utilities for the consumers and provides employment opportunities for the people in the developing countries. In Nigeria, fishing is an income generating activity and its marketing by women contribute substantially to raising the living standard of families (Engberg, 1988). FAO (2007) described poverty reduction in fisheries communities as a situation where people become measurably better off over time owing to their involvement and/or investment in fisheries or fisheries-related activities. In NEEDS (2004), it was reported that poverty reduction was the most difficult challenge facing Nigeria and her citizens and also a major hurdle that must be overcome in the pursuit of sustainable socio-economic growth.

Problem statement: In Nigeria, available statistics indicates that poverty is deep and pervasive. The poverty rate of the population increased from $27 \%$ in 1980 to about $70 \%$ by 1996 . By 1999 , it was estimated that more than $70 \%$ of Nigerians lived in poverty (NEEDS, 2004). Qualitatively, poverty in Nigeria has many manifestations and dimensions, including joblessness, over-indebtedness, economic dependence at adult age, lack of freedom, and inability to provide the basic needs of life for self and family. The broad objective of this study was to determine the extent to which fish trading contributed to the socio-economic enhancement of families while the specific objective was to investigate how fish marketing by women in a locality of low economic activity has affected the socio-economic status of women vis-à-vis helping to alleviate poverty.

\section{MATERIALS AND METHODS}

This survey was conducted in Abeokuta Township the capital of Ogun State, located within Latitude $7^{\circ} 9^{\prime} 0^{\prime \prime} \mathrm{N}$ and Longitude $3^{\circ} 2^{\prime} 0^{\prime \prime} \mathrm{E}$. The study covered only fish sellers that have stalls in the markets and those that retail their fish within the vicinity of fish deport (known as "cold rooms"). Respondents were randomly selected from all major markets and cold rooms within the study area in locations at Adatan, Adigbe, Iberekodo, Isabo, Itoku, Kuto, Olomore, Omida and Osiele. The questionnaires were administered to $10 \%$ of the total population of fish traders in each location. A total of one hundred and twenty (120) respondents correctly completed the structured questionnaire, out of the one hundred and fifty (150) administered. This 120 questionnaire were used for data analysis. Descriptive statistics were used to analyze the data generated from the questionnaires.

\section{RESULTS AND DISCUSSION}

The Abuja declaration in 2005, recognized promotion of trade in fish and fishery products as a tool of alleviation of poverty, promotion of household food security, empowerment of stakeholders for equitable allocation of resources and harnessing the entrepreneurship potential of women who have been in the forefront leading the development of fish processing and trade (NEPAD, 2005; Béné and Heck, $2005 b$ ). From this survey, it was found that all respondents (fish traders) were women (Table 1). Socio-economic characteristics of respondents show (Table 2) that $28.3 \%$ of respondents were able to meet their family responsibilities alone based on income from fish trading while most $(60.8 \%)$ met family responsibility co- 
jointly with their spouses. This agree with FAO (2009) report which emphasized that in addition to contributing to economic activity, employment and in generating foreign exchange, trade in fish and fishery products plays an important role in improving food security and contributing to fish products meeting nutritional needs. Almost half $(\approx 47 \%)$ of the respondents have five children and above. In addition to meeting household needs (food, clothing, housing, healthcare and also catering for an un-employed husband), over three quarter of the children of the respondents were found to be in school. World Bank (2004) reported that over 40\% of children in sub-saharan African countries do not finish their primary education. However, this study has shown that while $50 \%$ of the children of respondents are in post-primary institutions, more than $29 \%$ have their children in primary institutions, thus indicating that profit from fish trading has helped in socio-economic enhancement of the families.

This study further revealed that $12.5 \%$ of the respondents in Abeokuta had access to credit. In an attempt to overcome the challenge of fund limitation, FAO (2003) prescribed microfinance programmes with the aim to promote and protect income and empower these population segments. Because women constitute a significant proportion of poor fishing households, microfinance can also serve as an effective tool to assist and empower women in fishing communities. The overwhelming percentage of respondents $(83.4 \%)$ who expressed acceptance and willingness to continue with the business is not surprising as consumer theory has assured growth in the demand for good quality fish as long as there is growth in population, income and urbanization (FAO, 2002). This large majority of the respondents who said they would like to continue with the trade might apparently be due to the profit they make from the business. The profit margin has made the business attractive to new entrants which represented half of the sample population. In view of this interest, and the employment opportunity it provides for both young and middle aged $(\approx 80 \%)$, there is an urgent need of public and private investment to support this small-scale marketing initiatives so that they can grow their businesses. Such initiatives could improve food and nutritional security dramatically while fostering economic empowerment of the women traders (Béné and Heck, 2005a).

The percentage of respondent's spouses who were un-employed was $13.3 \%$ while most were artisans (46.7\%). Only a few $(10 \%)$ were civil servants. A respectable percentage of the respondents were also able to meet up with other family responsibilities such as the education of their children. The results of this study showed that majority of respondents' children were in school: $37.5 \%$ in secondary schools, $29.2 \%$ in primary schools and $12.5 \%$ in tertiary institutions. About $20.8 \%$ of the respondent's children were not in any educational institution, these included respondents who were single and those whose children were either of pre-school age or apprentices. Many of the respondents were new entrants into the business $(50 \%)$ while a number of them $(12.5 \%)$ had been in the business for five and above years. Majority $(86.7 \%)$ of the respondents were willing to continue with the trade (Table 3). This study also revealed that most of the respondents $(50.8 \%)$ set up the business through personal savings.

\section{CONCLUSION}

This study has demonstrated that women engaged in fish trading can generate wealth for their families and the nation, distribute benefits, make unique and vital contributions to human development, and provide leverage to address strategic questions of resource governance. In view of this interest, and the employment opportunity it provides there is an urgent need of public and private investment to 
support the women with innovative marketing initiatives so that they can grow their businesses through provision of access to credit like microfinance which can serve as an effective tool to assist and empower women engaged in fish trading in both rural and urban communities. Since the major policy thrust of NEEDS in respect of women is to fully integrate them through enhancing their capacity to participate in the economic, social, political and cultural life of the country, concerted effort should be made to the realization of this government policy.

\section{REFERENCES}

Aall, C. (1982). Fish protein resources for human consumption. Nutrition Bulletin Vol.4 , No.4.

Agbon, A.O., Agbon, C.A. and Adekoya, F.T. (2000). An economic analysis of fish marketing in Abeokuta, Ogun State. Aquafield $1: 8-19$.

Al-Jufaili, M.S. and Opara, L. U. (2006). Status of fisheries Postharvest Industry in the

Sultanate of Oman: Part1 Handling and Marketing System of Fresh Fish. Journal of Fisheries International 1 (2-4):144-149.b

Béné, C. and Heck, S. (2005a). Fish and food security in Africa. NAGA, 28(3\&4):8-13.

Béné, C. and Heck, S. (2005b). Fisheries and Millenium Development Goals: Solutions for Africa. 28(3\&4):14- 18.

CoF (Fisheries Society of Nigeria Council of Fellows) (2010). The contribution of fisheries sector to Nigerian economy. Press Briefing, $9^{\text {th }}$ July, 2010.

Davies, R.M, Davies, A.O and Abowei, J.F.N: (2009).d The Status of Fish Storage Technologies in Niger Delta Nigeria. American Journal of Scientific Research, ISSN 1450223X Issue 1, pp.55-63

Engberg, L.E. (ed.) (1988). Rural households, resouAASrce allocation and management. An Ecosystem perspective. FAO, Rome. 162pp.

Eurofish-FAO (2007). Global Fish Trade

Overview. Eurofish-FAO

Workshop, Split, Croatia, May 2007.

FAO. (2002). Workshop on promotion of sustainable commercial aquaculture in Zambia and Malawi, Lusaka, Zambia, 2-4 October 2002.

FAO. (2003). Microfinance in fisheries and aquaculture: guidelines and case studies, by U. Tietze and L.V. Villareal. FAO Fisheries Technical Paper No. 440. Rome.

FAO. (2007). Increasing the contribution of small-scale fisheries to poverty alleviation and food security, by $\mathrm{C}$. Béné, G. Macfadyen and E.H. Allison. FAO Fisheries Technical Paper No. 481. Rome.

FAO (2009). The State of World Fisheries and Aquaculture 2008. Food and Agriculture Organization of the United Nations, Rome, Italy. P196.

Gregory, D.H., Ganesh, P.R. and Robert, H.O. (1994). Using consumer profile to increase the U.S. market for seafood. Aquaculture 127(4): 303-316.

NEEDS (2004). NIGERIA: National Economic Empowerment and Development Strategy. National Planning Commission, Federal Secretariat, Abuja. 125pp.

NEPAD (2005). New Partnership for Africa's Development. The Abuja Declaration on Sustainable Fisheries and Aquaculture in Africa, Adopted by the Heads of State meeting of the NEPAD Fish for All Summit, Abuja, Nigeria, 25 August 2005. In: NAGA, 28 (3 \& 4): $19-22$.

Offem, B.O., Ikpi, G.U. and Adinya, I.B. (2008). Economic appraisal of the inland artisanal fishing industry in Cross River State, Nigeria. Aquafield, 4:23 - 32 
World Bank (2004). World Development

World Bank.

Indicators. Washington, DC: The

Table1: Demographic characteristics of respondents.

\begin{tabular}{|c|c|c|}
\hline $\begin{array}{l}\text { Personal } \\
\text { characteris } \\
\text { tics }\end{array}$ & $\begin{array}{l}\text { Numb } \\
\text { er }\end{array}$ & Percentage \\
\hline \multicolumn{3}{|l|}{ Age (years) } \\
\hline$<15$ & - & - \\
\hline $15-21$ & 9 & 7.5 \\
\hline $22-26$ & 19 & 15.8 \\
\hline $27-32$ & 28 & 23.3 \\
\hline $33-45$ & 40 & 33.3 \\
\hline $\begin{array}{ll}45 & \text { and } \\
\text { above } & \end{array}$ & 24 & 20.0 \\
\hline Total & 120 & 100 \\
\hline \multicolumn{3}{|c|}{ Marital Status } \\
\hline Single & 2 & 1.7 \\
\hline Married & 88 & 73.3 \\
\hline Divorced & 18 & 15.0 \\
\hline Widow & 12 & 10.0 \\
\hline Total & 120 & 100 \\
\hline \multicolumn{3}{|c|}{ Family Type } \\
\hline $\begin{array}{l}\text { Monogamo } \\
\text { us }\end{array}$ & 34 & 28.33 \\
\hline Polygamous & 54 & 45.0 \\
\hline Others & 32 & 26.67 \\
\hline Total & 120 & 100 \\
\hline \multicolumn{3}{|c|}{ Number Of Children } \\
\hline 0 (No child) & 5 & 4.2 \\
\hline $1-2$ & 27 & 22.5 \\
\hline $3-4$ & 32 & 26.7 \\
\hline 5 and above & 56 & 46.7 \\
\hline Total & 120 & 100 \\
\hline
\end{tabular}

Table 2: Socio-economic characteristics of respondents

\begin{tabular}{lll}
\hline Personal characteristics & Number & Percentage \\
\hline Occupation Of Spouse & & \\
Civil servant & 24 & 20.0 \\
Company worker/employee & 12 & 10.0 \\
Artisan & 56 & 46.7 \\
Fisherman & 12 & 10.0 \\
Unemployed & 16 & 13.3 \\
Total & 120 & 100 \\
Family Up-Keep & & \\
Husbands' responsibility & 13 & 10.8 \\
Self & 34 & 28.3 \\
Joint & 73 & 60.9 \\
Total & 120 & 100 \\
Educational Level Of Children (Institution) \\
Nil & 25 & 20.8 \\
Primary & 35 & 29.2 \\
Secondary & 45 & 37.5 \\
Tertiary & 15 & 12.5 \\
Total & 120 & 100 \\
\hline
\end{tabular}


Table 3: Marketing characteristics of the respondents.

\begin{tabular}{lll}
\hline Characteristics & Number & Percentage \\
\hline Years in business & & \\
$<2$ & 60 & 50 \\
$3-4$ & 45 & 37.5 \\
5 and above & 15 & 12.5 \\
Total & 120 & 100 \\
& & \\
Capital source & & \\
Personal savings & 61 & 50.8 \\
Loan & 15 & 12.5 \\
From spouse & 34 & 28.3 \\
From extended family & 10 & 8.3 \\
Total & 120 & 100 \\
& & \\
Interest in trade & & \\
Satisfactory & 106 & 83.4 \\
Not satisfied & 4 & 3.3 \\
Indifferent & 10 & 8.3 \\
Total & 120 & 100 \\
& & \\
Willingness to continue & & \\
Positive & 104 & 83.4 \\
Negative & 7 & 5.8 \\
Indifferent & 9 & 7.5 \\
Total & 120 & 100 \\
\hline
\end{tabular}

